\title{
Implicit vs explicit evaluation: How English-speaking Twitter users discuss migration problems
}

\author{
Elena V. GABRIELOVA ${ }^{\mathbf{1}}$ and OIga I. MAKSIMENKO ${ }^{\mathbf{2}}$ \\ ${ }^{1}$ National Research University Higher School of Economics \\ Moscow, Russia \\ ${ }^{2}$ Moscow Region State University \\ Mytishchi, Russia
}

\begin{abstract}
The current research answers the question how Twitter users express their evaluation of topical social problems (explicitly or implicitly) and what linguistic means they use, being restricted by the allowed length of the message. The article explores how Twitter users communicate with each other and exchange ideas on social issues of great importance, express their feelings using a number of linguistic means, while being limited by a fixed number of characters, and form solidarity, being geographically distant from each other. The research is focused on the linguistic tools employed by Twitter users in order to express their personal attitude. The subject chosen for study was the migration processes in Europe and the USA. The aim of the current investigation is to determine the correlation between the attitudes of English-speaking users towards migration and the way they are expressed implicitly or explicitly. The authors make an attempt to define which tools contribute to the implicit or explicit nature of the utterances. The material includes 100 tweets of English-speaking users collected from February 1 to July 31, 2017. The choice of the time period is defined by significant events in Trump's migration policy and their consequences. The research is based on the content analysis of the material carried out by means of the Atlas.ti program. The software performs the coding of textual units, counts the frequency of codes and their correlation. The results of the research show that Twitter users tend to express their critical attitudes towards migration, rather than approve of it or sympathise with migrants. Criticism is more often expressed implicitly rather than explicitly. In order to disguise the attitude and feelings, the English-speaking users of Twitter employed irony, questions and quotations, while the explicit expression of attitudes was done by means of imperative structures. It is also worth mentioning that ellipses, contractions and abbreviations were used quite frequently due to the word limit of tweets. At the same time, the lack of knowledge about extralinguistic factors and personal characteristics of users makes the process of interpretation of tweets rather challenging. The findings of the current research suggest the necessity to take into account implicit negative attitudes while carrying out the analysis of public opinion on Twitter.
\end{abstract}

Keywords: linguistic tools, implicit evaluation, explicit evaluation, Twitter, online communication, migration 
For citation:

Gabrielova, Elena V. \& Olga I. Maksimenko. 2021. Implicit vs explicit evaluation: How English-speaking Twitter users discuss migration problems. Russian Journal of Linguistics 25 (1). 105-124. DOI: 10.22363/2687-0088-2021-25-1-105-124

Научная статья

\title{
Имплицитная vs эксплицитная оценка:
} как англоязычные пользователи Twitter обсуждают проблемы миграции

\author{
Е.В. ГАБРИЕЛОВА ${ }^{1}$, О.И. МАКСИМЕНКО ${ }^{2}$
}

${ }^{1}$ Национальный исследовательский университет «Высшая школа экономики» (ВШЭ) Москва, Россия

${ }^{2}$ Московский государственный областной университет (МГОУ) Мытищщи, Россия

\begin{abstract}
Аннотация
Данное исследование отвечает на вопрос, каким образом (имплицитно или эксплицитно) и при помощи каких лингвистических средств пользователи Twitter выражают свое мнение об актуальной социальной проблеме в условиях ограниченности количества символов в сообщении. В статье подробно рассматривается влияние ограниченного количества символов в сообщении Twitter на выбор лингвистических средств пользователями для выражения своего мнения и эмоциональной оценки социально значимого события. Исследование сфокусировано на способах выражения оценки проблемы миграции в Европе и США англоязычными пользователями микроблога Twitter. Цель исследования заключается в установлении связи между эксплицитным или имплицитным способом выражения оценки и ее эмоциональной составляющей (выражающей одобрение или критику). Анализ проводился посредством использования программы компьютерного контент-анализа Atlas.ti. Корпус языкового материала составил 100 твитов. Период сбора материала для анализа (февраль-июль 2017 г.) обусловлен важными событиями в миграционной политике США и ее трагическими последствиями. Результаты исследования показали, что наибольшее количество сообщений выражает негативное отношение к миграционным процессам в США и Европе, а также недовольство проводимой миграционной политикой. Критика часто имплицируется при помощи иронии, вопросительных конструкций и цитат, в то время как императивные конструкции чаще всего были использованы в эксплицитных высказываниях. Англоязычные пользователи микроблога часто используют аббревиатуры, сокращения и эллиптические конструкции, что может быть обусловлено текстовым ограничением сообщений. Авторы исследования приходят к выводу, что, несмотря на определенную анонимность, предоставляемую коммуникацией в интернет-пространстве, пользователи Twitter склонны имплицировать негативные высказывания в адрес политических структур. Интерпретация скрытых смыслов сообщений усложняется отсутствием экстралингвистических факторов и личных характеристик коммуникантов. Результаты исследования свидетельствуют о необходимости учета импликации негативной оценки при использовании микроблога Twitter в качестве источника материала для анализа общественных настроений.
\end{abstract}

Ключевые слова: миграция, лингвистические средства выразительности, имплицитная оценка, эксплицитная оценка, Twitter 


\section{Для цитирования:}

Gabrielova E.V., Maksimenko O.I. Implicit vs explicit evaluation: How English-speaking Twitter users discuss migration problems. Russian Journal of Linguistics. 2021. Vol. 25. № 1. P. 105-124. DOI: 10.22363/2687-0088-2021-25-1-105-124

\section{Introduction}

The emergence of new tools for socialising has changed the process of communication and influenced the language people use to exchange information and personal opinions. Modern communication channels provide users with the opportunity to form communities on the basis of political views and attitudes. Social media facilitate communication between various people and, consequently, enable citizens to organise protests and encourage them to participate in political and social events (Gabrielova 2014, Schultz, Utz, Göritz 2011). Scholars have established an interconnection between political institutional trust and the will to share political views with other users (Klaase 1999). Such a will can be implemented through social media which provide opportunities for an exchange of information and opinions. Once people become members of a certain community, their trust increases and, consequently, they are eager to take part in political activities. Political discussions also contribute to political knowledge and form tolerance towards people with an opposite point of view (Brundidge 2010). At the same time, they provide an opportunity for an exchange of opinions and consolidation of users with the same points of view into certain groups or unities. New ways of information consumption and an alternative space for political discussion lead to certain transformations in the patterns of communication and participation in political events. Moreover, the platform offers a number of research possibilities across a variety of fields, such as political science, sociology, and linguistics. The Twitter data remain available on a long-term basis and can be analysed through user-based or content-based research approaches, including quantitative and qualitative methods. Twitter has been researched by scholars from a variety of fields, especially concerning its contribution to political discourse at times of social crises or elections.

Investigations by Alsaeedi (2019) and Nagarajan \& Gandhi (2019) focus on the sentiment analysis of Twitter. There are a number of techniques used to detect sentiment of opinions in tweets. The authors suggest frameworks for Twitter sentiment analysis and focus more on the technical details of the procedure rather than linguistic peculiarities of the language used in tweets. Wirawanda \& Wibowo (2018), explore hate speech on Twitter and view it as one of the discourse strategies without providing a linguistic analysis of the tools employed. Villarroel Ordenes et al. (2017), have carried out the analysis of explicit, implicit, and discourse patterns of sentiment in social media. The study focuses on the ways which consumers imply, or state explicitly, the sentiment in their reviews. Certain expressions and indicators were analysed through computer-based programs, and the results demonstrated the influence of consumer reviews on sales. The authors proved that consumers might influence each other's behaviour through implicit or explicit 
reviews. The paper makes a contribution to psycholinguistics, while the findings might be also used in marketing. The content analysis of Twitter, done by T. Basáñez et al. (2018), was aimed at examining tweets about e-cigarettes and vaping. The scholars used a pattern of analysis similar to the one employed in the current research. They collected a sample of tweets, where the authors stated explicitly or implied their attitude to vaping. Nevertheless, the goal of their investigation was to categorise tweets according to nine thematic categories and define the author of the message (a marketer or a non-marketer) rather than to look at the forms of linguistic expression in tweets.

Although there are a number of studies related to the content analysis of Twitter, we are not aware of any works devoted to the investigation of linguistic features of tweets devoted to the discussion of social issues, like migration processes. It should be noted that the migration problem arouses such emotions as anxiety, anger, hope and joy that motivate people to discuss the issue and share their views explicitly or implicitly (Benski et al., 2013). These emotions help the participants of the discussion to experience solidarity, recognition and empowerment, derived from their encounter with others in similar situations (Benski et al. 2013), which can be facilitated by the use of social networking tools such as Twitter. They produce a sense of connectedness, elaborate the feeling of solidarity as the participants of communication read about others, both distant and close, tackling the same problem of migration processes. The expression of personal opinions on Twitter is one of the tools that might affect a group of users and engage them in a discussion. Some scholars claim that sharing emotions in discourse can be regarded as an intention to arouse a certain emotional reaction from the counterpart or influence the addressee, either unconsciously or deliberately (Belyakov 2015: 125).

The current research is aimed at exploring the role of the English language in articulating personal opinions, examining the average number of implicit and explicit utterances in 100 tweets on the migration problem, as well as analysing the correlation between attitudes to migration and delivery methods through which they are expressed. The paper proposes the hypothesis that criticism tends to be articulated implicitly rather than explicitly. The main linguistic devices to veil the meaning of the utterance are irony and questions. These hypotheses are based on our previous studies of tweets devoted to protest movements in the USA (Gabrielova 2014, 2015).

\section{Theoretical Background}

\section{The migration problem}

The migration issue was chosen on purpose. First, this problem is topical in a number of English-speaking countries, and evokes a variety of feelings in people all over the world. The migration processes resonate through every level of society and are widely discussed on Twitter. On the one hand, migration can reduce the pressure on the labour market in countries where emigration exceeds immigration 
and encourage people to do manual work in the countries where the opposite is true, providing migrants with low-skilled positions. On the other hand, migration might cause financial problems in the developed countries, reducing the working opportunities for natives and an increase in the crime rates (De Haas et al. 2019). The situation is getting worse in terms of national tension which leads to social stratification.

The consequences of migration forced a number of countries to review their migration policies. According to the International Organisation for Migration (IOM), the whole number of international migrants in 2018 is in excess of 244 million people, i.e. 3.3\% of the world's population (World Migration Report 2018). European countries attempt to reduce the number of migrants by means of adopting certain regulations, but that leads to a rising number of illegal immigrants. Half of the population sympathises with the difficulties that migrants face; others criticise the current migration flow and form protests. In the USA, there was also a gap between supporters and protesters of migration policies by Trump in 2017, according to which the number of immigrants admitted to the USA was to be reduced. The law provoked discontent among immigrants and native citizens of the USA, including a number of organisations. At the same time, part of the population backed up the president, in the fear of terrorist acts or economic recession (Kozlovskij 2017). Ebzeeva and Karabulatova state that "processes of globalisation and migration specify the nature and status of ethnolinguistic mental cultures in net communication. According to the scholars, the spheres of basic ethnic and linguamental interrelation embrace: 1) cultural and civilisational interrelation (positive, progressive, consensus and conflict); 2) state policy in social sphere (language and culture); 3) aggressive promotion of western mass culture; 4) post-reactions to globalisation and migration processes" (Ebzeeva, Karabulatova 2017). This means that the verbalisation of personal opinions about migration processes reflects part of the ethnolinguistic mental culture of English-speaking Twitter users.

\section{Linguistic tools for expressing opinions}

In linguistic research, the information is explored from different perspectives. It is usually expressed through suppositions, opinions and statements. An utterance is comprised of a number of layers which differ in the meaning, being more or less explicit. Further statements are normally categorised into evident (explicit) and hidden (implicit). An explicit meaning is clearly decoded from the form of the statement. In contrast, an implicit meaning is established through an additional analysis of the utterance. Evident meanings are explicitly presented in the lexicosemantic structure of a sentence (Baranov 2007), insists on the binary nature of the explicit-implicit constituent of the linguistic content. Baranov regards ellipses and sentences with anaphoric pronouns as explicit statements. The meaning of such statements is reconstructed from the context of communication. It is well known that not all cases of ellipses correspond to explicit forms of presenting data. Baranov suggests classifying idioms as both explicit and implicit tools of information 
transition. Scholars believe that presuppositions and consequences have an implicit nature (Baranov 2007: 40). The current paper focuses on the implicit and explicit verbalisation of personal assessment. Sharafutdinova claims that verbal assessment is seen as a means of producing a certain influence on a communicator. Implicit assessment can be aimed at forming mental assessment patterns in the collective consciousness (Sharafutdinova 2009). Consequently, appealing to the experience and intellectual pool of the recipient of the message creates an illusion of selfdirected assessment and can be seen as a manipulative tool of managing an individual's opinion.

Linguistic means of assessment are divided into three categories: lexical, stylistic (metaphor, epithet, comparison, irony, allusion) (Pechenikhina 2008), and syntactic (sentences with assessing constructions and rhetorical questions) (Popova, Sternin 2007). Other scholars also include, in this category, quotations and lexis with expressive connotations (Sharafutdinova 2009). Pechenikhina (2008), singles out a concept of ironic modality as one of the types of subjective modality which is expressed through two polar assessments of the same object in a single utterance. Such type of irony is frequently used in political discourse and will be considered in the present study. One of the hypotheses of the current paper is that a tweet, restricted to 140 characters (currently the number of characters has been increased to 280) encourages Twitter users to employ a number of linguistic devices to express their opinions and attitudes explicitly or implicitly. The research also claims that the choice of linguistic means depends on the topics of tweets and the tone of opinion (positive or negative).

\section{Data and analytical framework}

Most frequently, the focus of the research is placed on personalised texts, such as tweets, blogs and reviews. This empirical material attracts scholars due to its subjective nature. Such texts contain a significant number of objects for the analysis, the relationships between them and implicitly expressed authors' opinions. This complicates the procedure of examining such texts and requires a unique corpus of collected linguistic material for the analysis (Semina \& Maksimenko 2019: 107). The current research is done through the analysis of 100 tweets tagged \#immigration, \#migrants, \#migration, and dated February - July 2017. The period was defined according to the events that drew a wide response in the USA and abroad. In January 2017, the president of the USA, Donald Trump, issued a policy aimed at decreasing the number of incoming immigrants which provoked much discussion both on Twitter and offline. It led to a number of protests and numerous tweets. In July 2017, ten immigrants were found dead inside a truck, in a parking lot, in Texas. The other 30 were taken to hospital (Montgomery 2017). Some people considered that tragedy to be a consequence of Trump's policy, while others acknowledged that the problem had already existed for a long time. The period chosen for the analysis (February 1, 2017 - July 31, 2017) embraces both events and opinions of the public which are clearly reflected in the tweets under 
analysis. The search commands "since" and "until", coupled with definite dates, gives an opportunity to extract tweets with a particular tag for a chosen time period. The first step was to analyse the authors of the messages. The tweets from individuals were included in the sample for further investigation. Messages from unions and organisations were disregarded. Next, we examined the tone of tweets, with the use of the Atlas.ti program, in order to reveal explicit and implicit attitudes of Twitter users towards migration.

\section{Research methods}

Traditional types of analysis. One of the possible ways to investigate linguistic means is through traditional grammatical analysis, which includes the study of morphology, phonology and semantics. It also comprises grammatical description and structural analysis. In order to characterise the structure of different languages, we used the descriptive approach, while the structural approach was aimed at investigating the distribution of forms in a language (Yule 1996).

Computer-mediated program Atlas.ti. In the present study, we employ Atlas.ti software, which is considered to be user-friendly and trustworthy. Therefore, defining language peculiarities of tweets and analysing their implicit or explicit nature, was carried out with the help of this application. It makes it possible to retrieve, structure and code chosen elements from the bulk text. The main function of the software is coding. It is performed through marking the text units (words or word phrases) and categories (blocks of elements) as separate codes. Coded words are allocated in groups depending on the aims of the research. Categorisation of text units depends on their meaning and is related to the chosen criteria. The outcomes of the data processing, codes, groups and their interrelation, may be presented in the form of schemes, tables and diagrams. Prior to the content analysis, we defined the tone of tweets (either criticising or supporting migration). One of the assumptions of the current research is that there are a number of linguistic tools which are used by Twitter users (on purpose or subconsciously) to make a message implicit or explicit. The investigation involves the analysis of such linguistic phenomena as quotations, irony, imperative constructions, idiomatic expressions and questions. Afterwards, we explored the correlation between the tone of the tweet, its nature (explicit or implicit) and linguistic tools exploited by the users to express the opinion.

\section{Results}

According to the obtained results, the authors of the explored tweets were both men and women. A great number of messages for the defined period were generated by organisations and news media. However, the investigation was based on the analysis of the tweets of ordinary users. The majority of tweets $(53 \%)$ criticised contemporary migration processes, both legal and illegal. More than a quarter of the users $(28 \%)$ articulated their approval of migration and backed up immigrants. A smaller percentage of messages (23\%) showed discontent with the migration 
policy by D. Trump. The tweets, generated to inform other users of events and sharing a link to an external source of information, comprised almost one third (29\%) of all investigated messages. Figure 1 presents the ratio of topics in FebruaryJuly 2017.

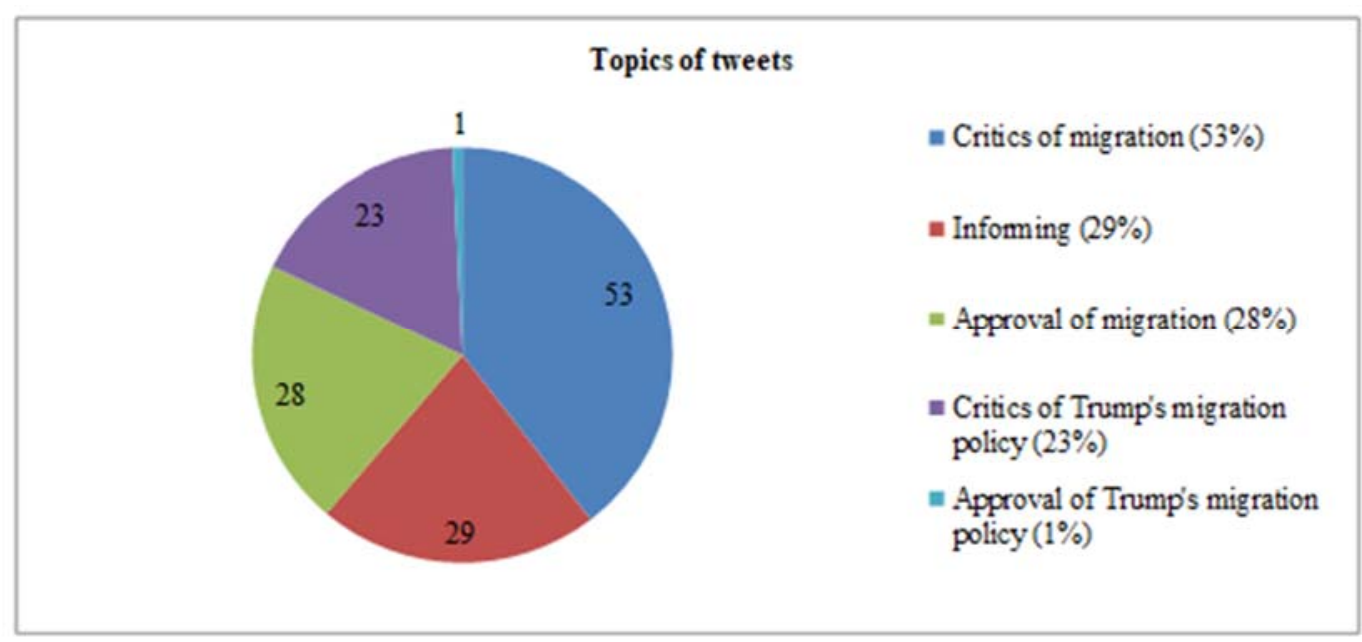

Fig. 1. Topics of tweets in February - July 2017

As it is shown in Figure 1, the number of people criticising migration processes on Twitter is significant and comprises $53 \%$ of all messages.

(1) "The increase of population is always a challenge for a city to face" @NesreenBarwari on \#migration http://www.citiestobe.com/article/aglimpse-into-global-challenges-through-global-experts ....

(2) Will Europe Restrict African Migration? http://flip.it/NixcoR \#migration

(3) Islam has conquered Italy without firing a shot! More than 5M jihadists have invaded Italy, 37\% of the pop, is expected to be Foreigners.

The examples demonstrate that in order to criticise the migration processes, Twitter users exploited such tools as questions, quotations, exclamations and words with negative meaning: "restrict" (2), "challenge" (1), "invaded" (3), "conquered" (3). The word "restrict" in the second message points to limiting control or someone's actions or movements (The Longman Dictionary of Contemporary English). The author of the tweet asks a question whether Europe would limit the control or movement of African migration, showing his/her resentment. In contrast, the word "conquer" is defined in The Longman Dictionary of Contemporary English as "to get control over a country by fighting" and at the same time "to become very successful in a place". Example (3) expresses the author's reaction to the fact that Islam took control over Italy without any fight and has become quite successful there. The idea is also articulated through the word "invaded", which is defined as "to enter a country... in order to take control" or "to get into a place in large numbers, especially when you are not wanted". The danger of losing control over the country discomforts the author of this message. 
The messages supporting migration are fewer.

(4) The United States was founded as, and continues to be, a country of immigrants from throughout the world/1 \#DemPartyPlatform \#Immigration. (5) We need \#immigrants to keep Italian social welfare going - not just economics btw, but social care and quality of life for us all \#migration .

(6) What happened to "UNITED States of America the Melting Pot" this country was built through immigration. Everyone here is an immigrant other.

(7) It really is such a broad issue that I think in many ways we need to climb out of our heads and into our hearts. \#Immigration .

The support for migration, both in Europe and the US, is expressed through the modal verb "need", which encourages people to act (5); an inversion "it really is such a broad issue" (7); a metaphor "climb out of our heads and into our hearts" (7); supergraphic tools "UNITED" (6). The main idea of such messages is that all people should be tolerant to migrants. Messages (4) and (6) even allude to the history of the US, pointing out the origin of the US population. In contrast to message (3), the author of message (5) expresses the need for migrants to maintain social welfare in Italy. The message reflects current polarisation of opinions on migration issues in the society.

A lot of people in the US were dissatisfied with the migration policy of Donald Trump, who pursued the law in January 2017, banning the entry of immigrants from a number of countries. The initiative raised discontent among the population that was widely expressed on Twitter:

(8) Draconian \#immigration policies create the climate of fear \& exploitation that leads to completely preventable deaths. \#TX, repeal \#SB4 .

(9) Father of 4 deported last wk. It doesn't have to be this way.@realDonaldTrump \#Immigration \#StopSeparatingFamilies http://www.cleveland.com/metro/index.ssf/2017/07/willard_father_says_goo dbye_to.html...

(10) Sadly the very thought of \#Trump as POTUS has probably already lowered the \#immigration rate just by sheer disgust and disapproval. \#Resist. (11) Trump \#immigration crackdown threatens morale of US troops overseas by putting \#PIP in limbo.

The given tweets demonstrate the use of the contraction "wk" (9) and eye-catching reference "POTUS" (10), a negative structure coupled with a modal verb "doesn't have to be" (9), negative markers "draconian" (8), "fear \& exploitation" (8), "crackdown threatens" (11), "sheer disgust and disapproval" (10). The word "draconian" is defined by The Longman Dictionary of Contemporary English as "very strict and cruel". The author coupled this adjective with "fear and exploitation", which demonstrates a common negative attitude towards D. Trump's migration policy. The author of message (9) disapproves of the policy by implying that separating family members should not be allowed, and this is a wrong policy to follow. At the same time, it is not quite obvious, whether the author is against the immigration process itself or supports it. 
The most frequent tweets criticising the migration policy by Trump were noted in July 2017, because of the tragedy in Texas. The authorities found eight bodies in a tractor-trailer in a Walmart parking lot, which appeared to be smuggling migrants. Some experts named it "an unintended consequence of enhanced border enforcement and security measures" (Montgomery 2017). The above-mentioned incident evoked empathy among the US population, and raised discontent with the taken measures in terms of migration in the US.

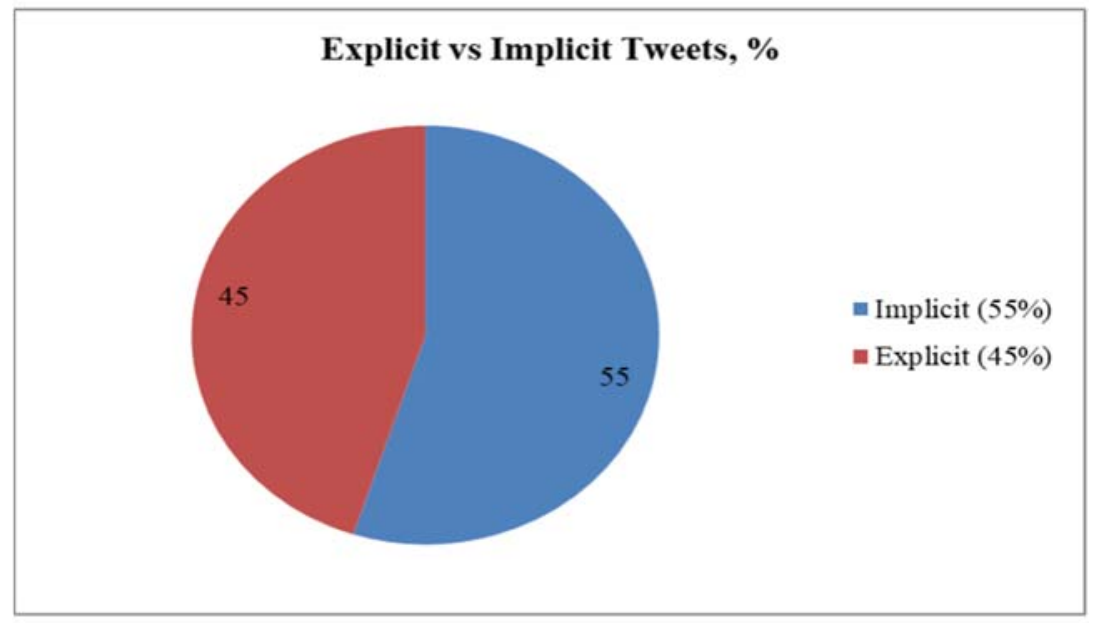

Fig 2. The ratio of explicit and implicit tweets

As illustrated in Figure 2, the number of implicit tweets (55\%) slightly exceeds the number of explicit ones (45\%).

(12) The consequences of global population changes will affect billions - we will need to revise \#migration policies and our economic models (.

(13) "Imagine that you see the wretched strangers, Their babies at their backs and their poor luggage" https://www.playshakespeare.com/sir-thomasmore/scenes/1193-act-ii-scene-4 ... \#migration.

(14) More than 3000 polish immigrants each year are extradited because of crimes. Why are we letting people in? \#Immigration \#crime.

In example (12) the user demonstrates his point of view through the modal verb "will", which is accompanied by the word "need" and, in this particular context, expresses the necessity and encourages acting. The verb "affect" is often considered to carry a negative meaning, and implies an unfavourable attitude of the user towards the problem of migration.

The author of tweet (13) encourages people to imagine a miserable situation. $\mathrm{He} / \mathrm{she}$ uses an extract from "Sir Thomas More" by William Shakespeare. Through the quotation the user draws people's attention to migration issues in Europe and the USA in 2017, without being transparent and stating explicitly his/her position regarding the problem. Quotation marks disguise the meaning of the message, giving readers a hint at the play where the sheriff of London is willing to conciliate the rebellion of journeymen against foreigners. 
The message (14) provides statistical information followed by a question. The author draws the readers' attention to the facts and migration results, making people reflect on the causes of the situation. Through the analysis of the facts and consequences the author of the message implies his/her negative attitude towards migration. The hashtags to this message place immigration and crime in the same line, drawing a link between these two phenomena.

(15) We have to take back control of our own countries and get rid of these backward barbarians by any credible means. \#italymigrants \#migration.

(16) Efforts to Rescue Migrants Caused Deadly, Unexpected Consequences https://nyti.ms/2snjyEy \#migration.

(17) Words are meaningful, so let's be sure to use the right ones. It's not immigration It's an invasion \#AltRight \#Immigration \#Invasion \#Europe.

The authors of the tweets given above explicitly express their opinion on the migration processes through the epithets "deadly" (16), "unexpected" (16), a word phrase "get rid of these backward barbarians" (15), which appear to be the negative connotation markers, and demonstrate the users' unfavourable attitude towards migration. The author of message (15) again mentions control and the need for taking it back from immigrants. Immigrants are presented as backwards "developing slowly and less successfully than others"; barbarians - "someone from a different land, who does not behave properly". These words explicitly express the disgust of the Twitter user towards migrants in Italy. Two of the given tweets encourage people to act through the suggestive "let's" (17) and the modal verb "have to" (15). The negative impression is supported by the juxtaposition "It's not immigration. It's invasion" (17). Again, invasion is mentioned, which means that a lot of people arrived being unwanted, and took control over the country. Message (16) appeals to the measures that were taken to rescue migrants, and characterises these measures as "deadly", which means lethal or causing harm. Consequently, the message expresses disapproval of the migration policy.

The results of the linguistic analysis of tools by Atlas.ti program are shown in Figure 3. Each linguistic phenomenon was used as a separate code.

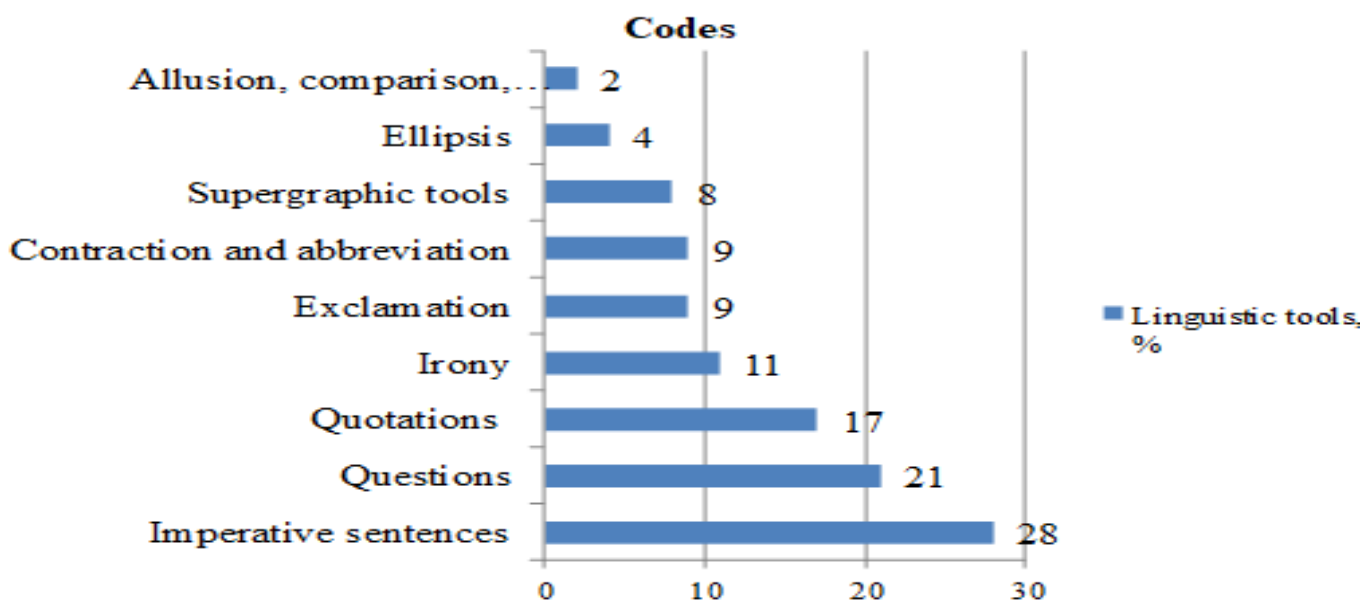

Fig 3. Codes in February - July, 2017 
As demonstrated in Figure 3, almost one third of the analysed tweets have an imperative nature. Among those $10 \%$ contain an imperative structure. In other cases, encouragement is realised through modal verbs expressing the need for action and obligation, and the subjunctive mood.

(18) The consequences of global population changes will affect billions we will need to revise \#migration policies and our economic models.

(19) We must secure the borders. "FOLLOW" us if you agree!

(20) If the \#US wants to know how \#immigration affects a country, it can look to how \#European \#immigrants impacted the indigenous population .

In example (18) the author expresses the need for action through the modal verbs "need" and "will". Tweet (19) illustrates the use of the modal verb "must", the subjunctive mood "if you agree", and an imperative construction with an eyecatching font "FOLLOW". Message (20) demonstrates the call for action through the subjunctive mood and the modal verb "can". The adjective "indigenous" points out the critical opinion of the author towards immigrants, who impacted the native people's life.

As shown in Figure 3, questions are used in $21 \%$ of tweets. It is interesting to note that half of them are aimed at criticising the migration processes.

(21) A solution to \#migration \& \#employment issues in \#Africa? Remote working@Tolu_Olubunmi@rajdeyhttp://owl.li/X71b30dDcaE.

(22) More than 3000 polish immigrants each year are extradited because of crimes. Why are we letting people in? \#Immigration \#crime.

(23) And danger of cutting legal \#Immigration channels, pushing \#immigration into black market. Yet \#GOP pushing to cut visas more. \#MAGA?.

Example (21) contains a question-objectification. First, the author of the utterance asks a question and then provides an answer to it. Such a technique is aimed at creating an impression that a reader, and not the author of the message, has given the answer. By means of this tool the author imposes his/her view on the readers, even though it is not stated clearly, but is expressed through the question. Tweets (22) and (23) depict the question-discussion. There is an affirmative sentence in the first place in each case followed by a question, which encourages the reader to find an answer to it. Example (22) is a real picture of the outcome of Trump's migration policy. The author uses the acronym \#MAGA (Make America Great Again), which corresponds to Trump's slogan during the election campaign. The question mark at the end of the sentence demonstrates doubts concerning the president's policy and its positive influence on the country's welfare. Example (23) speaks about the extradition of Polish immigrants, committing crime, and questions the roots of the issue mentioned in the message. The authors use questions to highlight the problem of migration and attract public attention to it.

Figure 3 demonstrates how the Twitter users also make use of quotations and aphorisms. In most cases they contribute to the implicit nature of tweets, as the use 
of quotation marks is typical for implying the meaning of the utterance. In the current research, quotations are regarded as both words taken from the speech of celebrities and given with quotation marks and reposts of tweets and news from other users' accounts.

(24) "Imagine that you see the wretched strangers, Their babies at their backs and their poor luggage" https://www.playshakespeare.com/sir-thomasmore/scenes/1193-act-ii-scene-4 ... \#migration

(25) "The increase of population is always a challenge for a city to face" @NesreenBarwari on \#migration http://www.citiestobe.com/article/aglimpse-into-global-challenges-through-global-experts ... \#CitiesToBe.

(26) \#Trump is trumped again! Court says "grandparents are the epitome of close family members". \#TravelBan \#immigration .

Example (24) contains an extract from Shakespeare's play "Sir Thomas More" and was mentioned above. It is aimed at raising compassion and pity towards migrants. In tweet (25) the quotations serve to criticise migration as a negative phenomenon for the receiving country. There is also a reference to the primary source of information. Example (26) demonstrates not only the use of a quotation, but also a pun "Trump is trumped". The author of the tweet mocks Trump's migration policy, and provides the evidence of its inconsistency in quotation marks. According to the court's decision, grandparents are regarded as close relatives and receive the right to stay in the country.

The next code that was used is irony $(11 \%)$. It is exploited to imply a negative view on migration processes.

(27) Many of our ancestors would not have qualified under today's immigration laws. https://www.americanimmigrationcouncil.org/research/ did-my-family-really-come-legally-todays-immigration-laws-created-a-newreality ...@immcouncil \#immigration.

(28) DOJ is now officially using the term illegal alien Guess we all have to be politically correct \#MAGA \#Immigration .

In example (27) the user refers to predators, in other words, immigrants in the historical past of the USA, who invaded the country and took control over it. The author makes an attempt to apply Trump's migration policy to them and shows its inconsistency. Only the context helps to decode the author's disapproval of Trump's migration policy. It proves the implicit nature of the statement reached through the use of irony. Example (28) contains an allusion to the Department of Justice (DOJ) and its decision to employ the term "illegal alien", which can be also used to describe "a hypothetical or frictional being from another world" (Lexico, UK Dictionary). The author of the tweet suggests that everyone should be politically correct, and it appears from the context that the term "illegal alien" does not meet this requirement. In such an implicit way the author conveys his/her negative attitude towards the migrants and migration. 
Such linguistic devices as exclamation and contraction were used equally (9\% each). Exclamation was widely used in implicit statements criticising migration. Exclamatory sentences deliver the emotional state of the participants of communication. Expressing feelings and emotions on the existing problem facilitates uniting people sharing the same opinion, no matter what their geographical position is. Such emotions as anger, joy and anxiety contribute to establishing solidarity and participating in protests and demonstrations (Benski et al. 2003). Therefore, Twitter users are emotional in expressing their opinion about migration:

(29) The SCANDAL over@BBC not paying men \& women the same for the same job is echoed in \#immigration: Brits, if fairly paid, can pick crops too!.

(30) That melting pot was created by LEGAL \#immigration with immigrants who came to \#America to assimilate \& honor our laws, not change them!

In the given examples we can also observe the use of supergraphemic tools capital letters in "LEGAL" and "SCANDAL", which attract the reader's attention and make emphasis in the statement. In example (30) the author highlights the fact that immigrants are due to accept the laws, but not to influence them. Such means were used in $8 \%$ of tweets, especially those that criticised migration.

Abbreviations and contractions are not frequent (9\%). Nearly the same trend is true for ellipsis $(4 \%)$ - an expected linguistic tool due to the restricted length of a tweet:

(31) Day 48. \#100DaysOfCode Got an introduction to "migration" process and started to implement it. \#Migration \#Database \#Data \#Java \#Code.

(32) Are there people dumb enough to believe Dems care abt \#immigration out of a sense of compassion?! All Dems view immigrants as $\underline{r}$ VOTES.

The examples of allusion, subjunctive mood and comparison are infrequent $(2 \%)$.

Having analysed the choice of words in all tweets through Wordclouds.com, we have obtained the following results, presented in Figure 4.

The word search was done comprising hashtags from the analysed tweets. The most frequently used words appeared to be immigration, migration and Europe. It shows that the problem is especially topical in European countries. America and the US were also mentioned, but not as often as Europe. Twitter users expressed their attitude with the help of the verbs "need" and "will" (each word was used 9 times). This proves the people's desire to change the current situation. The word "policy" was mentioned 6 times ("policies" and "laws" 5 times each) which also demonstrates the interest of Twitter users in migration policies that are developed or should be employed. The abbreviation "MAGA" is used 4 times in order to point out Trump's promise to "make America great again". The context of such messages allows us to make a conclusion that users do not trust the promise and speak of it ironically. 


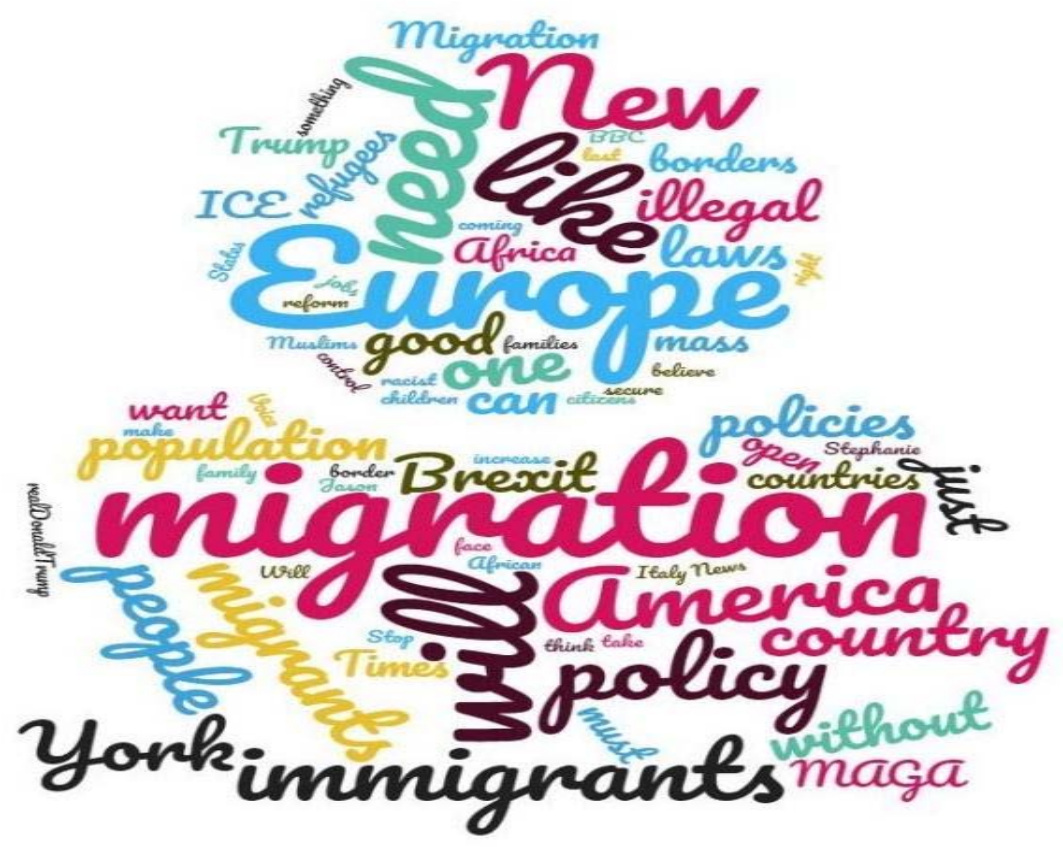

Fig.4. A word cloud of tweets

\section{Discussion}

The results of the current research prove that the majority of implicit tweets contain criticism of the migration process in Europe and the USA. It is worth mentioning that most of the explicit tweets were also aimed at expressing disapproval of migration. Moreover, Twitter users tend to employ various stylistic and syntactic devices, which means that negative feelings and emotions encourage people to use a number of linguistic tools in order to express their critical point of view both explicitly or implicitly. Criticism of migration was the most popular attitude among all of the tweets analysed. It proves the fact that migration was a topical issue at the time of analysis and provoked much discontent among Twitter users. The most widely used tools for expressing a personal opinion were imperative sentences and questions, whereas exclamations, irony and metaphors were used less frequently. Twitter users associate migrants with invaders, and are reluctant to pass on the control over the country to them. The use of vocabulary implies that immigrants are seen by the disapproving Twitter users as unwanted and less civilised people. The current research proves that the choice of linguistic tools is closely related to the nature of the message (either explicit or implicit). Twitter users imply their opinion through irony, quotations and questions, while explicit tweets frequently have imperative structures. Moreover, English speaking users of Twitter employ contractions and abbreviations more often than ellipses. The reason for that could be the restriction of the length of a tweet to 280 characters and the need to share as much emotion or information as possible.

It is interesting to note that despite the opportunity to conceal the names and articulate the position openly without being identified, users still hesitate to express 
their negative attitude towards political leaders and their policies explicitly. It demonstrates the power of the ruling authorities and the need to take into account the reluctance of Twitter users to freely demonstrate their personal assessment of politically and socially significant events. The investigation also highlights the peculiarities of Twitter as a means of communication and a data source for linguistic analysis. Tweets can be highly public or intensely personal. Certain tools, such as hashtags, help to collect the empirical data on a particular topic and form a linguistic corpus for the analysis. Although one of Twitter's assets is considered to be the ability to obtain interesting insights from short and highly context-bound messages, they are still difficult for interpretation due to a number of meanings and possible bias.

The current research has been limited to the content analysis of tweets devoted to the migration processes. Although a traditional content analysis was implemented as a primary methodological tool for the analysis of tweets, it has revealed a number of limitations: external validity in the linguistic analysis of single sentences and phrases, as content analysis might be extremely selective in its approach. A computer-aided Atlas.ti program was employed in order to minimise the limitation. Computer-mediated analysis, used in the current research, was accompanied by traditional content analysis. It contributed to classifying numerous tweets and grouping relevant concepts. The procedure, implemented in the investigation, can be replicated by other researchers at a minimal cost.

\section{Conclusion}

The aim of the current research was to establish a correlation between the attitudes of English-speaking users towards migration issues and the way of their expression: implicit or explicit. In the investigation the authors described the tools that contribute to the implicit or explicit nature of the opinions. Besides, it was discovered how evaluation of contemporary social issues are expressed on Twitter (explicitly or implicitly), and what linguistic devices are used under the circumstances of a strong limitation of the message length. The article demonstrates the patterns of people communication on Twitter, the way they share their ideas on hot social issues and express their feelings, using a number of linguistic devices, while being limited by a fixed number of characters, and how they form solidarity, while being geographically apart. The research results are of a significant value for linguistics, as they might be used in investigation of the defined patterns through the prism of social events, and in the analysis of the linguistic material following the computer procedure described in the article.

(C) Elena V. Gabrielova and Olga I. Maksimenko, 2021 


\section{REFERENCES}

Alsaeedi, Abdullah \& Mohammad Zubair Khan. 2019. A study on sentiment analysis techniques of Twitter data. International Journal of Advanced Computer Science and Applications 10 (2). 361-374.

Bamman, David, Jacob Eisenstein \& Tyler Schnoebelen. 2014. Gender identity and lexical variation in social media. Journal of Sociolinguistics 18 (2). 135-160. DOI: 10.1111/ josl.12080

Baranov, Anatoliy. 2007. Lingvisticheskaja jekspertiza teksta. Teoreticheskie osnovanija i praktika [The Linguistic Expertise of a Text. Theoretical Foundations and Practice]. Moscow, Russia: Flinta: Nauka.

Baron, Naomi S. 2008. Always on: Language in an Online and Mobile World. Oxford: OUP.

Basáñez, Tatiana, Anuja Majmundar, Tes Boley Cruz \& Jeniffer B. Unger. 2018. Vaping associated with healthy food words: A content analysis of Twitter. Addictive Behaviors Reports 8. 147-153. DOI: 10.1016/j.abrep.2018.09.007

Belyakov, Mikhail. 2015. Emotive character of a diplomatic discourse. Russian Journal of Linguistics 2. 124-132.

Brundidge, Jennifer. 2010. Encountering "difference" in the contemporary public sphere: The contribution of the Internet to the heterogeneity of political discussion networks. Journal of Communication 60 (4). 680-700. DOI: 10.1111/j.1460-2466.2010.01509.x

De Haas, Hein, Stephen Castles \& Mark J. Miller. 2019. The Age of Migration: International Population Movements in the Modern World. Guilford Press.

Crystal, David. 2001. Language and the Internet. Cambridge: CUP.

Earl, Jennifer, \& Katrina Kimport. 2011. Digitally Enabled Social Change: Activism in the Internet Age. MA: MIT Press, Cambridge.

Ebzeeva, Julija \& Irina Karabulatova. 2017. Novye aspekty issledovanija kommunikacii v sovremennyh social'nyh setjah. [New aspects of the research of communication in contemporary social networks]. The Bulletin of the Adyghe State University, the series "Region Studies: Philosophy, History, Sociology, Jurisprudence, Political Sciences and Culturology" 4 (209). 258-267.

Fischer, Eilee \& Rebecca A. Reuber. 2011. Social interaction via new social media: (How) can interactions on Twitter affect effectual thinking and behavior? Journal of Business Venturing 26 (1). 1-18. DOI: 10.1016/j.jbusvent.2010.09.002

Gabrielova, Elena. 2014. New media in the protest movement: explicit and implicit expression of point of view on the protest movement Occupy Wall Street on Twitter. Journal of Psycholinguistics 3 (21). 150-159.

Gabrielova, Elena. 2015. Implicit and explicit ways of expressing personal opinion on Twitter: The Tea Party movement in the USA. (Working Paper N. 90). Working Papers of Humanities: National Research University Higher School of Economics.

Greenhow, Christine \& Benjamin Gleason. 2012. Twitteracy: Tweeting as a new literacy practice. The Education Forum 76 (4). 464-478. DOI: 10.1080/00131725.2012.709032

Greenhow, Christine \& Beth Robelia. 2009. Informal learning and identity formation in online social networks. Learning Media and Technology 34 (2). 119-140. DOI: 10.1080/ 17439880902923580

Hardy, Bruce W. \& Dietram A. Scheufele. 2005. Examining differential gains from Internet use: Comparing the moderating role of talk and online interactions. Journal of Communication. International Communication Association 55 (1). 71-84. DOI: 10.1111/ j.1460-2466.2005.tb02659.x 
Kaase, Max. 1999. Interpersonal trust, political trust and non-institutionalised political participation in Western Europe. West European Politics 22 (3). 1-21. DOI: 10.1080/ 01402389908425313

Maksimenko, Olga \& Tatiana Semina. 2019. Sozdanie korpusa tekstov dlya analiza tonal'nosti [Creating a corpus for sentiment analysis]. Proceedings of National Association of Applied Linguistics 3 (27). 106-114.

Nagarajan, Senthil Murugan \& Usha Devi Gandhi. 2019. Classifying streaming of Twitter data based on sentiment analysis using hybridization. Neural Computing and Applications 31 (5). 1425-1433. DOI: 10.1007/s00521-018-3476-3

Pechenikhina, Ekaterina. 2008. Yazykovoe vyrazhenie ironii v proizvedeniyakh Zh.M. Esy de Keyrosha [Verbal expression of irony in works by Esy Keyrosh]. Moscow University Philology Bulletin 4. 140-147.

Pennebaker, James W., Martha E. Francis \& Roger J. Booth. 2001. Linguistic inquiry and word count: LIWC 2001. Mahway: Lawrence Erlbaum Associates, 71.

Pennebaker, James W. 1993. Putting stress into words: Health, linguistic, and therapeutic implications. Behaviour Research and Therapy 31 (6). 539-548. DOI: 10.1016/00057967(93)90105-4

Porter, Lance, Kaye Sweetser \& Deborah Chung. 2009. The blogosphere and public relations. Investigating practioner's role and blog use. Journal of Communication Management 13 (3), 250-267. DOI: 10.1108/13632540910976699

Popova, Zinaida \& Iosif Sternin. 2007. Obshchee Yazykoznanie [General Linguistics]. 2nd edn. Moscow: AST: Vostok-Zapad.

Renkema, Jan. 2009. The Texture of Discourse. Towards an Outline of Connectivity Theory. Amsterdam: John Benjamins Publishing Company.

Rojas, Hernando \& Eulalia Puig-i-Abril. 2009. Mobilizers mobilized: Information, expression, mobilization and participation in the digital age. Journal of Computer-Mediated Communication 14 (4). 902-927. DOI: 10.1111/j.1083-6101.2009.01475.x

Sharafutdinova, Svetlana. 2009. Sportivnaya analiticheskaya stat'ya kak zhanr diskursa SMI [Sport analytical article as a genre of mass media discourse]. Bulletin of Chelyabinsk State University 34 (172). 141-145.

Schultz, Friederike, Sonja Utz \& Anja Göritz. 2011. Is the medium the message? Perceptions of and reactions to crisis communication via twitter, blogs and traditional media. Public relations review 37 (1). 20-27. DOI: 10.1016/j.pubrev.2010.12.001

Simon-Vandenbergen, Anne-Marie, Miriam Taverniers \& Louise J. Ravelli. 2003. Grammatical Metaphor: Views from Systemic Functional Linguistics. Amsterdam: John Benjamins Publishing Company.

Stemler, Steve. 2001. An overview of content analysis. Practical Assessment, Research \& Evaluation 7 (17). DOI: 10.7275/z6fm-2e34

Stubbs, Michael. 1983. Discourse analysis: the sociolinguistic analysis of natural language. Chicago: University of Chicago Press.

Tejerina, Benjamin, Ignacia Perugorría, Tova Benski \& Lauren Langman. 2013. From the streets and squares to social movement studies: What have we learned? Current Sociology 61 (4). 541-561. DOI: 10.1177/0011392113479753

Villarroel Ordenes, Francisco, Stephan Ludwig, Ko De Ruyter, Dhruv Grewal \& Martin Wetzels. 2017. Unveiling what is written in the stars: Analyzing explicit, implicit, and discourse patterns of sentiment in social media. Journal of Consumer Research 43 (6). 875-894. DOI: $10.1093 / \mathrm{jcr} / \mathrm{ucw} 070$

Vlieger, Esther \& Loet Leydesdorff. 2011. Content analysis and the measurement of meaning: The visualization of frames in collections of messages. The Public Journal of Semiotics 3 (1). 321-339. 
Wirawanda, Yudha \& Tangguh Okta Wibowo. 2018. TWITTER: Expressing Hate Speech Behind Tweeting. Profetik: Jurnal Komunikasi 11 (1). 5-11. DOI: 10.14421/ pjk.v11i1.1378

Yule, George. 1996. The Study of Language. 2nd ed. Cambridge: CUP.

Zanzotto, Fabio Massimo, Marco Pennacchiotti \& Kostas Tsioutsiouliklis. 2011. Linguistic redundancy in Twitter. Proceedings of the 2011 Conference on empirical methods in natural language processing. Edinburgh, Scotland, 659-669.

\section{Internet resources}

Kozlovskij, Vladimir. 2017. Storonniki Trampa: "Strana bez granic - jeto ne strana" (Trump supporters: "The country without borders is not a country"). Russian BBC. URL: http://www.bbc.com/russian/features-38807554 (accessed: 10 March 2020).

Montgomery, David, Manny Fernandez \& Yonette Joseph. 2017. Journey fatal for 9 migrants found in truck in a San Antonio parking lot. The New York Times. URL: https://www.nytimes.com/2017/07/23/us/san-antonio-truck-walmart-trafficking.html (accessed: 8 June 2020).

World Migration Report. The international organization for migration. URL: $\mathrm{https}: / / \mathrm{www}$.iom.int/wmr/world-migration-report-2018

Zimmer, Ben. 2011. On the front line of Twitter linguistics. [Blog post]. URL: http://languagelog.ldc.upenn.edu/nll/?p=3536> (accessed: 8 June 2020).

\section{Article history:}

Received: 16 June 2020

Accepted: 26 January 2021

\section{История статьи:}

Дата поступления в редакцию: 16 июня 2020

Дата принятия к печати: 26 января 2021

\section{Bionotes:}

Elena V. GABRIELOVA is Ph.D., Senior Lecturer at the School of Foreign Languages at the National Research University "Higher School of Economics". Her research interests include applied linguistics, political and mass communication, personal evaluation and emotions in Internet discourse, as well as political communication.

\section{Contact information:}

National Research University "Higher School of Economics"

Myastnitskaya str., 20, Moscow, 101000

e-mail: evgabrielova@hse.ru

ORCID: 0000-0002-0813-9264

Olga I. MAKSIMENKO is Dr. habil., Professor at the Faculty of Linguistics at Moscow Region State University. Her research interests embrace applied linguistics, quantitative linguistics, linguoconflictology, diplomatic discourse and sentiment analysis.

\section{Contact information:}

Moscow Region State University

Very Voloshinoy street, 24, Mytishchi, Moscow Region, 141014

e-mail:maxbel7@yandex.ru

ORCID: 0000-0002-6611-8744 
Сведения об авторах:

Елена Валерьевна ГАБРИЕЛОВА - кандидат филологических наук, старший преподаватель Школы иностранных языков Национального исследовательского университета «Высшая школа экономики». Сфера ее научных интересов включает языкознание, прикладную лингвистику, политическую коммуникацию, массовую коммуникацию, интернет-дискурс, оценочные суждения и эмотивность в интернетдискурсе.

\section{Контактная информация:}

Национальный исследовательский университет «Высшая школа экономики» Москва, 101000, ул. Мясницкая, 20

e-mail: evgabrielova@hse.ru

ORCID: 0000-0002-0813-9264

Ольга Ивановна МАКСИМЕНКО - доктор филологических наук, профессор кафедры теоретической и прикладной лингвистики Московского государственного областного университета. Сфера ее научных интересов включает языкознание, прикладную лингвистику, квантитативную лингвистику, лингвоконфликтологию, дипломатический дискурс, лингвистическую теорию эмоций, сентимент-анализ.

Контактная информация:

Московская область, 141014, Мытищи, ул. Веры Волошиной, 24

e-mail: maxbe17@yandex.ru

ORCID: 0000-0002-6611-8744 